\title{
Awareness of Farmers about Schemes for Doubling Farm Income
}

\author{
S. R. Gaikwad ${ }^{1 *}$, K. S. Thorat ${ }^{2}$, J. M. Deshmukh ${ }^{3}$ and V. B. Samrit ${ }^{1}$ \\ ${ }^{1}$ College of Agriculture, ${ }^{3}$ Department of Extension Education, Latur, India \\ ${ }^{2}$ Department of Extension Education, COA, Osmanabad, India \\ *Corresponding author
}

\section{A B S T R A C T}

\section{Keywords}

Doubling farm income, Awareness about schemes for Doubling farm income

\section{Article Info}

Accepted:

10 January 2021

Available Online:

10 February 2021
The present study was conducted in Latur and Osmanabad district of Marathwada region of Maharashtra stateIn latur district out of ten tehsils two tehsils where selected randomly namely Latur and Chakur and in Osmanabad district out of eight tehsils two tehsils where selected randomly namely Osmanabad and Kalamb. For the purpose of study 2 villages from each selected tehsils, (Total 2 X $4=8$ ) were selected randomly for the selection of. Thus total 8 villages were selected for study. From each selected village, 15 farmers were respondents selected randomly. In this way, a total of 120 farmers (Total 8 X $15=120$ ) were considered as respondent for the present study. These selections were done by using simple random sampling method for the purpose of the study. The result of Awareness showed that majority $(65.00 \%)$ of the respondents had medium level of awareness about schemes for doubling farm income followed by 20.00 and 15.00 per cent of the respondents had low and high awareness about the schemes for doubling farm income, respectively.

\section{Introduction}

Indian agriculture is essentially monsoon and market dependent, and suffers frequent distresses posing threat to the welfare of farmers as well as interest in farming. Agriculture plays a vital role in India's economy over 58.00 per cent of the rural households depend on agriculture as their principal means of livelihood of India. Agriculture along with fisheries and forestry, contributes to more than 16.00 per cent of Gross Domestic Product (GDP) of country however the growth in the Agriculture sector in 2015-16 continued to the lower than the average of the last decade. Declining farm productivity and income have serious implications on rural prosperity and overall economy hence increasing the real income, i.e. nominal (Actual) income adjusted to inflation has become a priority for the state and policy planners.

Announcing the target of doubling farmer's income by 2022, the Honorable Finance Minister (FM) in his Union Budget Speech 2016-17, had highlighted the need to think beyond food security of the country and to focus on income security of the farmer. This announcement was quite timely and probably 
the rising of agrarian distress and the two years of consecutive drought situation country has faced (Anonymous, 2016), the intent seems right, given the current state of India's agriculture and the plight of its farmers. Growth in farm income after 2011-12 has plummeted to around 01.00 percent, and this is an important reason for the sudden rise in agrarian distress in recent years (Chand et al., 2015). FM had also laid emphasis on the optimal utilization of the country's water resources, creation of new infrastructure for irrigation, conservation of soil fertility with balanced use of fertilizer, and provision of value addition and connectivity from farm to market

\section{Strategies for Improving Farmers Income}

\section{Development initiatives}

Some recent development initiatives of the central government aiming to raise output and reduce cost include:

\section{Pradhan Mantri Krishi Sinchai Yojana (PMKSY)}

It is national mission to improve farm productivity and ensure better utilization of the resources in the country.

The overreaching vision of PMSKY is to ensure access to some means of protective irrigation to all agricultural farms in the country to produce Per Drop More Crop thus bringing much desired rural prosperity.

\section{Major objectives}

1. Convergence of investment in irrigation at the field level

2. Expand cultivable area under irrigation (Har Khet KoPani)
3. Improve on-farm water used efficiency to reduce wastage of water

4. Enhance the adoption of being precise in irrigation and other water saving technologies (More Crop per Drop)

\section{Soil Health Card (SHC)}

Soil Health Card Scheme is a scheme launched by the Government of India in 19 February 2015. Under the scheme, the government plan to issue soil cards to farmers which will carry crop-wise recommendations of nutrient and fertilizers require for the individual farms to help farmers to improve productivity through judicious use of inputs.

All soil samples to be tested in various soil testing labs across the country. Thereafter the experts will analyse the strength and weakness of the soil and suggest measures to deal with it.

\section{Prampragat Krishi Vikas Yojana (PKVY)}

Paramparagat Krishi Vikas Yojana (PKVY) is an elaborated component of Soil Health Management (SHM) of major project National Mission on Sustainable Agriculture (NMSA)

\section{Objectives}

1. Promotion of commercial organic production through certified organic farming.

2. The produce will be pesticide residue free and will contribute to improve the health of consumer.

3. It will raise Farmer's income and create potential market for traders.

4. It will motivate the farmers for natural resource mobilization for input production. 


\section{Pradhan Mantri Fasal Bima Yojana (PMFBY)}

The Pradhan Mantri Fasal Bima Yojana (Prime minister's Crop Insurance Scheme) was launched by Prime Minister of India Narendra Modi on 13 February 2016.It is also called as risk management tool.

\section{Objectives}

1. Providing financial support to farmers suffering crop loss/ damage arising out of unforeseen events.

2. Stabilizing the income of farmers to ensure their continuance in farming.

3. Encouraging farmers to adopt innovative and modern agricultural practices.

4. Ensuring flow of credit to the agriculture sector which will contribute to food security, crop diversification and enhancing growth and competitiveness of agriculture sector besides protecting farmers from production risks.

\section{Materials and Methods}

The present study was carried out in the Latur and Osmanabad districts of Marathwada region of Maharashtra state. The Latur district is situated on the Balaghat Plateau, about 540 meters to 638 meters from the mean sea level and Osmanabad district lies in the southern part of state. It lies on the Deccan plateau, about $600 \mathrm{~m}$ above sea level 540 meters to 638 meters from the mean sea level. The total area of Latur district is 7371 sq.km and the total area of Osmanabad district is 7569 sq. $\mathrm{km}$. the total population of latur district is $2,454,196$ and total population of Osmanabad district is $1,657,576$ (2011 census). In latur district, Manjara is the main river which flows on the Balaghatplatueau along with its tributaries: Terna, Tawarja and Gharni and osmanabad district is Parts of the sina, Manjira and Terna River flow through the district.The present investigation was carried out in two randomly selected districts out of the total 8 districts of Marathwada region namely Latur and Osmanabad district. In latur district out of ten tehsils two tehsils where selected randomly namely Latur and Chakur and in Osmanabad district out of eight tehsils two tehsils where selected randomly namely Osmanabad and Kalamb. For the purpose of study 2 villages from each selected tehsils, (Total 2 X $4=8$ ) were selected randomly for the selection of respondents. Thus total 8 villages were selected for study. From each selected village, 15 farmers were selected randomly. In this way, a total of 120 farmers (Total 8 X $15=120$ ) were considered as respondent for the present study. These selections were done by using simple random sampling method for the purpose of the study.

\section{Results and Discussion}

\section{Awareness of farmers about schemes for Doubling farm income}

It concluded that the majority $(65.00 \%)$ of the respondents had medium level of awareness about schemes for doubling farm income followed by 20.00 and 15.00 percent of the respondents had low and high awareness about the schemes for doubling farm income

\begin{tabular}{|c|c|c|c|}
\hline SI.No. & Category & Frequency & Percentage \\
\hline $\mathbf{1 .}$ & Low (up to 13) & 24 & $\mathbf{2 0 . 0 0}$ \\
\hline $\mathbf{2 .}$ & Medium (14-25) & 78 & $\mathbf{6 5 . 0 0}$ \\
\hline $\mathbf{3 .}$ & High (Above 25$)$ & 18 & $\mathbf{1 5 . 0 0}$ \\
\hline & Total & $\mathbf{1 2 0}$ & $\mathbf{1 0 0 . 0 0}$ \\
\hline
\end{tabular}


Table 1 revealed that scheme-wise awareness of respondents about schemes for Doubling Farm Income in that all respondents i.e 100 percent of respondents had aware of the Pradhan Mantri Fasal Bima Yojana scheme. Overwhelming majority $(98.33 \%)$ of the respondents had aware about Nanaji Deshmukh Krishi Sanjivini Yojana (POCRA) and only 1.67 percent of respondents were not aware of this scheme.

Overwhelming majority (95.83\%) of the respondents had aware about Pradhan MantriKisan Samman Nidhi and only 4.17 percent of respondents were not aware of this scheme.

Majority $(95.00 \%)$ of the respondents had aware of Pradhan Mantri Krishi Sinchai Yojana (PMKSY) and only 5.00 percent of respondents were not aware about this scheme.

Majority (93.33\%) of the respondents had aware of the Soil Health Card and only 6.67 percent of the respondents were not aware of the soil health card.

The majority $(91.67 \%)$ of the respondents had aware of the National Horticulture Mission (NHM) and National agriculture insurance Scheme (NAIS) of each and only 8.33 per cent of the respondents were not aware of NHM and NAIS of each.

The 90.00 per cent of the respondents were aware of the Kisan Credit Card Scheme (KCC) and only 10.00 per cent of the respondents were not aware of this scheme.

Followed by, 87.50 percent of the respondents were awareness of Pilot Crop Insurance Scheme (PCIS) and two-fourth (12.50\%) of the respondents were not aware of this scheme.
78.33 per cent of the respondents had awareness of Bhausaheb Fundkar Falbhag Lagvad Yojana and 21.67 per cent of the respondents were not aware of this scheme.

More than three-fourth (76.67\%) of the respondents had awareness about the Fodder Development Scheme and 23.33 percent of the respondents were not aware of this scheme.

Three-fourth $(75.00 \%)$ of the respondents were aware of Weather Based Crop Insurance Scheme (WBCIS) and one-fourth (25.00\%) of the respondents were not aware of WBCIS.

Less than three-fourth $(74.17 \%)$ of the respondents had aware of the Farm Income Insurance Scheme (FIIS) and slightly more than one-fourth $(25.83 \%)$ of the respondents were not aware of the FIIS scheme.

Slightly more than two-third $(67.50 \%)$ of the respondents was aware of the National Food Security Mission (NFSM) and 32.50 per cent of the respondents were not aware of NFSM.

Two-third (66.67\%) of the respondents were aware of Rashtriya Krishi Vikas Yojana (RKVY) and one-third (33.33\%) of the respondents were not aware of RKVY.

More than half $(55.83 \%)$ of the respondents had awareness about the Dairy Entrepreneurship Development Scheme and more than one-third $(44.17 \%)$ were not aware of Dairy Entrepreneurship Development Scheme.

More than half $(55.00 \%)$ of the respondents had aware of the National Mission on Oilseed and Oil palm and 45.00 per cent of the respondents were not aware of this scheme.

Slightly more than half $(52.50 \%)$ of the respondent had awareness about 
Comprehensive Crop Insurance Scheme and 47.50 percent of the respondents are not aware of this scheme.

Slightly more than half $(50.83 \%)$ of the respondents had aware of the Experimental Crop Insurance Scheme and 49.17 per cent of the respondents were not aware of this scheme. The 48.33 per cent of the respondents were aware of the Crop Pest Surveillance and
Advisory Project (CROPSAP) and more than half $(51.67 \%)$ of the respondents were not aware of this scheme.

47.50 per cent of the respondents were aware of the Mission for Integrated Development of Horticulture (MIDH) and more than half $(52.50 \%)$ of the respondents were not aware of MIDH.

Table.1 Scheme wise distribution of awareness level of farmers about schemes for doubling farm income

\begin{tabular}{|c|c|c|c|c|c|c|}
\hline \multirow[t]{3}{*}{ Sl.No } & \multirow[t]{3}{*}{ Schemes for Doubling Farm Income } & \multicolumn{5}{|c|}{ Response } \\
\hline & & \multicolumn{2}{|c|}{ Yes } & \multicolumn{2}{|c|}{ No } & \multirow[t]{2}{*}{ Rank } \\
\hline & & $\mathbf{F}$ & $\%$ & $\mathbf{F}$ & $\%$ & \\
\hline $\mathbf{A}$ & Crop Related Schemes & & & & & \\
\hline 1 & KrishiUnnatiYojana - & & & & & \\
\hline 1.1 & National food security mission (NFSM) & 81 & 67.5 & 39 & 32.5 & XIIII \\
\hline 1.2 & $\begin{array}{l}\text { National food security mission- } \\
\text { commercial crops }\end{array}$ & 44 & 36.67 & 76 & 63.33 & XXIIII \\
\hline 1.3 & $\begin{array}{l}\text { Missionfor Integrated Development } \\
\text { of Horticulture (MIDH) }\end{array}$ & 57 & 47.50 & 63 & 52.50 & XXI \\
\hline 1.4 & National mission on oilseed \& oil palm & 66 & 55.00 & 54 & 45.00 & XVII \\
\hline 1.5 & $\begin{array}{l}\text { National mission for sustainable } \\
\text { agriculture }\end{array}$ & 51 & 42.50 & 69 & 57.50 & XXII \\
\hline 1.6 & $\begin{array}{l}\text { National mission on Agricultural } \\
\text { extension and technology }\end{array}$ & 26 & 21.67 & 94 & 78.33 & XXVIII \\
\hline 2 & $\begin{array}{l}\text { NanajiDeshmukhKrishiSanjiviniYojana } \\
\text { (PoCRA) }\end{array}$ & 118 & 98.33 & 2 & 01.67 & II \\
\hline 3 & Kisan Credit Card (KCC) & 108 & 90.00 & 12 & 10.00 & VIII \\
\hline 4 & $\begin{array}{l}\text { Pradhan MantriFasalBimaYojana } \\
\text { (PMFBY) }\end{array}$ & 120 & 100 & 00 & 00 & I \\
\hline 5 & Pradhan MantriKisan Samman Nidhi & 115 & 95.83 & 5 & 04.10 & III \\
\hline 6 & RastriyaKrishiVikasYojana (RKVY) & 80 & 66.67 & 40 & 33.33 & XV \\
\hline 7 & Pradhan MantriKisanSampadaYojana & 30 & 25.00 & 90 & 75.00 & XXVII \\
\hline 8 & National Agro Forestry Policy & 1 & 00.83 & 119 & 99.17 & XXXIII \\
\hline 9 & $\begin{array}{l}\text { National Certificate System for Tissue } \\
\text { Culture Related Plants (NCS-TCP) }\end{array}$ & 00 & 00 & 120 & 100 & XXXV \\
\hline 10 & $\begin{array}{l}\text { Protection of Plant Varieties and rights of } \\
\text { farmers }\end{array}$ & 11 & 09.17 & 109 & 90.83 & XXIX \\
\hline 11 & ParamparagatKrishiVikasYojana (PKVY) & 40 & 33.33 & 80 & 66.67 & XXVI \\
\hline 12 & $\begin{array}{l}\text { Promotion of National Market through } \\
\text { Agri-Tech infrastructure Fund (AITF) }\end{array}$ & 4 & 03.33 & 116 & 96.67 & XXXI \\
\hline 13 & $\begin{array}{l}\text { Crop Pest Survillance and Advisory } \\
\text { project ofMH (CROPSAP) }\end{array}$ & 58 & 48.33 & 62 & 51.67 & $\mathrm{XX}$ \\
\hline
\end{tabular}




\begin{tabular}{|c|c|c|c|c|c|c|}
\hline 14 & BhausahebFundkarFalbagLagvadYojana & 94 & 78.33 & 26 & 21.67 & X \\
\hline 15 & National Horticulture Mission (NHM) & 110 & 91.67 & 10 & 08.33 & VI \\
\hline 16 & Crop Insurance Scheme & & & & & \\
\hline 16.1 & Pilot Crop Insurance Scheme (PCIS) & 105 & 87.50 & 15 & 12.50 & IX \\
\hline 16.2 & $\begin{array}{l}\text { National Agriculture Insurance } \\
\text { Scheme(NAIS) }\end{array}$ & 110 & 91.67 & 10 & 08.33 & VII \\
\hline 16.3 & Farm income Insurance Scheme (FIIS) & 89 & 74.17 & 31 & 25.83 & XIII \\
\hline 16.4 & $\begin{array}{l}\text { Comprehensive Crop Insurance Scheme } \\
\text { (CCIS) }\end{array}$ & 63 & 52.50 & 57 & 47.50 & XVIII \\
\hline 16.5 & $\begin{array}{l}\text { Experimental Crop Insurance Scheme } \\
\text { (ECIS) }\end{array}$ & 61 & 50.83 & 59 & 49.17 & XIX \\
\hline 16.6 & $\begin{array}{l}\text { Weather Based Crop Insurance Scheme } \\
\text { (WBCIS) }\end{array}$ & 90 & 75.00 & 30 & 25.00 & XII \\
\hline 17 & KisanVikasPatra (KVP) Re-introduced & 8 & 06.67 & 112 & 93.33 & $\mathrm{XXX}$ \\
\hline 18 & $\begin{array}{l}\text { Pradhan Mantri Krishi Sinchai Yojana } \\
\text { (PMKSY) }\end{array}$ & 114 & 95.00 & 6 & 05.00 & IV \\
\hline 19 & $\begin{array}{l}\text { Pradhan Mantri Sansad Adarsh Gram } \\
\text { Yojana }\end{array}$ & 43 & 35.83 & 77 & 64.17 & XXV \\
\hline 20 & Soil Health Card Scheme (SHC) & 112 & 93.33 & 8 & 06.67 & V \\
\hline B & Livestock and Poultry Related & & & & & \\
\hline 1 & National Livestock Mission & 46 & 38.33 & 74 & 61.67 & XXIII \\
\hline 2 & $\begin{array}{l}\text { Dairy Entrepreneurship Development } \\
\text { Scheme }\end{array}$ & 67 & 55.83 & 53 & 44.17 & XVI \\
\hline 3 & Fodder Development Scheme & 92 & 76.67 & 28 & 23.33 & XI \\
\hline 4 & $\begin{array}{l}\text { National Programme for Bovin breeding } \\
\text { and dairy development }\end{array}$ & 2 & 1.67 & 118 & 98.33 & XXXII \\
\hline 5 & $\begin{array}{l}\text { Dairy processing and infrastructure } \\
\text { development fund }\end{array}$ & 1 & 0.83 & 119 & 99.17 & XXXIIII \\
\hline
\end{tabular}

More than one-third (38.33\%) of the respondents were aware of National Livestock Mission and 61.67 per cent of the respondents were not aware of this scheme.

36.67 per cent of the respondents were aware of the National Food Security MissionCommercial crops and 63.33 per cent of the respondents were not aware of this scheme. 35.83 percent of the respondents were aware of Pradhan MantriSansad Adarsh Gram Yojana and 64.17 percent of the respondents were not aware of this scheme.

One-third $(33.33 \%)$ of the respondents were aware of Paramparagat Krishi Vikas Yojana (PKVY) and two-third (66.67\%) of the respondents were not aware of this scheme.

One-fourth $(25.00 \%)$ of the respondents were aware of Pradhan Mantri Kisan Sampada Yojana and three-fourth $(75.00 \%)$ of the respondents were not aware of this scheme.

The 21.67 percent of respondents had aware of National Mission on Agricultural Extension and Technology and more than three-fourth (78.33 $\%$ ) had not aware of this scheme.

Slightly less than two-fifth $(9.17 \%)$ of the respondents had aware of the Protection of Plant Varieties and Rights of Farmers and 90.83 percent of respondents were not aware of this scheme. Only 6.67 percent of respondents had aware of Kisan Vikas Patra (KVP) Reintroduced scheme and 93.33 percent of respondents had not aware of this scheme.

Only 3.33 percent of respondents had aware of 
the Promotion of National Market through AgriTech Infrastructure Fund (AITF) and 96.67 percent of the respondents had not aware of this scheme.

Only 1.67 per cent of the respondents were aware of National Programme for Bovine Breeding and Dairy Development and overwhelming majority $(98.33 \%)$ were not aware of this scheme.

Only 00.83 per cent of the respondents had aware of Dairy Processing and Infrastructure Developing Fund and National Agro-Forestry Policy and overwhelming majority $(99.17 \%)$ of the respondents were not aware of Dairy Processing and Infrastructure Developing Fund and National Agro-Forestry policy of each.

No one was aware about National Certificate Systems for Tissue Culture Related Plants (NCS-TCP).

The probable reason might be that some of the schemes that had very low awareness and medium awareness may be due to less education and because of medium level of mass media exposure, the knowledge regarding this scheme became low.

The report says that the benefits of government schemes and policies are being mostly given to big farmers having landholding of 10 acres (4.05 hectares) and above. In poor and small farmers category minimum farmers get benefited from government schemes and subsidies because of less awareness and farmers blamed the state and central governments for their present condition and they say that they cannot get any farming-related information from officials of the agriculture department.
In conclusion the important finding of study was that, majority $(65.00 \%)$ of the respondents had medium level of awareness about schemes for doubling farm income

\section{References}

Chand, R., Saxena, R. and Rana, S. 2015 Estimate and analysis of farm income in India, 1983-84 to 2011-12.Economics and Political Weekly. 50 (22): 139-145.

https://vikaspedia.in/agriculture/policies-andschemes/policy-paper-on-doublingfarmers-income

Mohapatra,L.,Dhaliwal,R.K. and Kaur,M. 2016 Farmers knowledge about the agricultural insurance scheme in Panjab.Indian Research Journal of Extension Education. 16(1):49-53.

Wani S. P., Vijay SandeepJakkula and Dhirendra Singh (eds.) 2017 Doubling farmers' Income: KISAN-MITrA. Proceedings of National Workshop on Doubling Farmers' Income through Scalingup: KISAN-MITrA (Knowledgebased Integrated Sustainable Agriculture Network - Mission India for Transforming Agriculture) Patancheru 502 324. Telangana, India. International Crops Research Institute for the SemiArid Tropics.

Dhande, S. J., 2017. Knowledge and attitude of farmers towards crop insurance scheme. M.Sc. (Agri.) Thesis, VNMKV, Parbhani.

Khandelwal, V. 2017. A study on awareness and benefits of Pradhan Mantri Jan DhanYojana. Imperial Journal of Interdisciplinary Research (IJIR).3 (3): 707-710.

\section{How to cite this article:}

Gaikwad, S. R., K. S. Thorat, J. M. Deshmukh and Samrit, V. B. 2021. Awareness of Farmers about Schemes for Doubling Farm Income. Int.J.Curr.Microbiol.App.Sci. 10(02): 1137-1143. doi: https://doi.org/10.20546/ijcmas.2021.1002.134 